\title{
3. Bad Governments Lose: Surely there is no mystery there
}

\author{
Rodney Cavalier
}

\begin{abstract}
In every choice between courage and safety, Labor chose safety. Across the full spectrum of supposed virtues, Labor chose the alternative. We witnessed a Labor campaign without courage, flair, imagination or principle. Technically, it was predictable, flat and no better than fair- average quality. The essence of the strategy was doing whatever it takes. Labor began by being as reckless as necessary to win-hence the matching of the tax cuts. Labor's recklessness was calculated. The absence of responsibility was based on the template of John Howard [in] 1996 and the three outings following. If politics is about winning - and it is hard to conjure any other purpose - the Labor campaign of 2007 was genius unparalleled.
\end{abstract}

- (Cavalier 2009, 201).

Humane but tough. Three words came to define the character of the Rudd Government. Words in a torrent became the response whenever the position to be taken was not safely predictable; a beguiling entrapment of self-contradiction of which the author seemed unaware. Australians became accustomed to fullblown bursts from a prime minister who had an opinion on everything, oft preceded by the non-apology 'I make no apology for'. We knew Kevin Rudd was opposed to Bill Henson taking photos of pre-pubescent girls, he was appalled at an assault on a female MP, and he regarded the response to climate change as the 'great moral challenge' of our times.

Outside such matters of moment, what exactly the Rudd Government stood for was not clear. Such concern was, to be sure, a boutique concern of political commentators and the dwindling band of ALP stalwarts who were wondering aloud what the new government had altered, bar the symbolics. Certainly, there had been the grand theatre of the Apology; there was the ratification. After which, there was?

In no time, 2007 became 2008 and politics meandered. The Coalition parties formed the scene of troubles. Brendan Nelson was an unlikely leader always. It did not assist that Peter Costello remained in the frame and in the Parliament, the obvious alternative, though by neither word nor deed did he encourage that possibility. Malcolm Turnbull-less circumspect, certainly less patientdid not conceal his intentions. 
Divisions in the other side were the most reportable show in town. The ALP at every level was four square behind its leader, the Prime Minister and election winner. Dissent and criticism had disappeared. The ordinary processes of Cabinet government broke down; caucus was neither bellwether nor monitor; the ALP National Secretariat regarded its role as discovering the wishes of the leader and delivering them. The ALP National Conference was a week in which democratic discourse went into exile. The party had become the captive of the political class - that narrow funnel of operatives on splendid salaries who work for the ALP machine, affiliated unions, the staffs of ministers and MPs. This was their government. This was their government untrammelled. The Rudd Government was going to provide a textbook on how a new model of Labor governance worked. In that it certainly succeeded. The model did not end with the demise of its author.

This chapter is about the government that fell on 21 August 2010. The election was in play after just one term of government because the incumbents lost the support of the Australian people. When the last vote was counted, it transpired that some 62 per cent of Australian electors had voted against the ALP; only in 1931 has the primary vote for Labor been worse.

\section{A Ship Moored in Indonesia}

The moment when private concerns about the Rudd Government became widespread public doubt was the response (or non-response) to the presence of the Oceanic Viking moored in Indonesian waters, holding seekers of asylum in Australia unwilling to disembark in Indonesia. The Indonesians were disinclined to compel the seekers to get off the ship. Australia's defence forces could not intervene. Vessels without a lawful right of entry had been seeking entry to Australia in numbers uncomfortable for the government. The cumulative impact of these arrivals occasioned grievous harm to the perception the government preferred of itself. With the Viking anchored and going nowhere, the rhetoric employed by Rudd was directed at one side of this debate. The government was determined not to allow a perception it was led by a bleeding heart. Humane, nonetheless, the government remained. We knew it was humane because we were told that so often.

The nerve refugees need to touch is reached by acts of commission and omission sufficient to cause embarrassment to an Australian government. That way, Australia's authorities will offer to have applications considered with expedition. Those on board the Viking jumped ahead of the orderly process that was considering pre-existing applications. Not that those who disembarked chose to disembark because there was a special deal for them. We know that the 
circumstance of their disembarkation was non-extraordinary - a lexical firstbecause the Prime Minister said so. The electorate was being asked to believe: 1) no special deal was offered the asylum-seekers on board the Oceanic Viking in order to induce them to disembark; but, if there was, then 2) the Prime Minister did not know the terms of any special deal offered to those asylum-seekers.

The then Leader of the Opposition, Malcolm Turnbull, was constrained in his criticism of the statements of his opposite. A highly vulnerable Prime Minister, having talked himself into a sea of troubles, was not eviscerated because the Opposition Leader dared not utter the accusation that the Prime Minister had misled the Parliament. In the absence of a direct accusation by the Opposition, the headlines were missing. Turnbull had disabled himself some months earlier by making the most extreme demand on the Prime Minister without building his scale of demands in lockstep with emerging evidence. Turnbull relied on the evidence of a public servant - evidence later revealed as tainted. Turnbull did not recover from that error. Turnbull was effectively dead in the water. He was holding on for the reason that no alternative Liberal leader wanted to lead the Coalition to defeat. The situation was similar to federal Labor in 2005-06 when the Beazley leadership was treading water.

While it might have suited the alternative Liberal leaders to allow Turnbull to take the Coalition to an overwhelming defeat, the Opposition Leader brought about his own ruin by attempting to compel the doubters in his party to back Rudd on the government's emissions trading scheme (ETS). Such zealotry by an Opposition leader in support of a government he is supposed to be opposing and against the opposition of a sizeable segment of the party he is leading is unique in the history of federation. What then followed was revealing of something quite shocking in modern politics: evidence of a critical mass of MPs and senators who believe in something other than their own careers. Believing in what they believe, these Liberals and Nationals advanced their cause by argument and memo, intrigue, dirty tricks, leaks, false rumour, challenges, resignations, text messages and statements on the record.

A novelty for modern times. A party divided on policy. A party divided by a debate on what should constitute its core beliefs. A party whose members hold their beliefs so dearly they placed those beliefs ahead of the unity of the party. A party whose differences could not be managed. The absence of any and all of those qualities in the modern Australian Labor Party is its greatest strength, so we are told. Labor knew what it believed about climate change because the leadership had promulgated an ETS as the way to proceed. In lockstep, no dissent audible, Labor followed its leadership. Twice legislation passed the House; twice it was rejected by the Senate. Yet the government-riding so high in the polls - chose not to take the issue to a double dissolution. 
Some of the reason for this caution were fear and uncertainty; some was the sheer pleasure of toying with the other side. Modern government seeks to make its Opposition the issue. For all of 2008, going into late 2009, it mattered not that many who actually believe in the need for action against climate changesuch as the Greens and respected scientists - attested the government's scheme was not worth a thimble of ice water. What mattered in terms of the politics was whether the government was prepared to risk all on implementing an ETS by making it the issue in a double dissolution. Malcolm Turnbull risked all in an attempt to deny the government the pleasures of this squeeze play. He duly lost all. He and the nation shortly discovered the Rudd Government was not prepared to risk anything.

As 2009 became 2010, a powerful question emerged: what exactly does this government intend to do about climate change? These were powerful, unsettling questions that Labor stalwarts were asking of their elected representatives. If polling picked up a sharp fall in support for the rhetoric coming from Rudd and his Climate Change Minister, Penny Wong, did anyone believe that the ALP federal leadership would commit itself to persuading the nation to accept what the pollsters were saying a majority did not believe in? Would the Labor leadership argue against the tides of popular opinion? There was a winning hand going into the 2007 election, a winning hand through 2007, 2008 and 2009. It helped Labor mightily that the Liberals were split and The Nationals opposed. Legislation did not come to pass; objective, favourable circumstance moved against the government. So much goodwill was lost by pursuing a phoney deadline ahead of the Copenhagen climate conference; not even the most enthusiastic believer in the dangers of climate change asserted that legislative action by Australia mattered a damn. By the end of 2009, ahead of Copenhagen, much more than goodwill was lost.

\section{Failing to Go Early}

Labor was to pay a heavy price - one seat short of the ultimate price-for the failure to go early. Through 2009 the possibilities of an early poll were under constant watch. With the Turnbull leadership floundering and the polls high for Labor wherever you looked-primary, two-party preferred, approval for Rudd, State-by-State federal voting intentions - the arguments against going early were not strong. Since the Second World War, prime ministers in their first term have taken an early election. The Menzies victory of 1949 was followed by a double dissolution in 1951. The great victory of 1972 was followed by a double dissolution in 1974. Changes of government since have followed that pattern: 1975 followed by 1977; 1983 by 1984; 1996 by 1998 . 
A decision not to take the plunge was not taken at a single meeting. The party leader has to be an enthusiast for the enterprise. The then Prime Minister was not. The party denied itself a certain five years in government and a probable eight in exchange for a wholly different atmosphere going into 2010; hardheads feared (and wrote at the time) that the winning of another three years was not going to be a lay-down misère. Failing to go early characterised the caution that beset the former government.

Street smarts did not countenance any possibility of a Labor defeat. (Street smarts being defined as a conventional wisdom not yet demolished by a real-world event.) Drilling into the reasons for a Labor victory was not all that flattering. Two factors were considered insurmountable obstacles to an Opposition in the first term of a government. One was the ancient truth that the punters do not want to admit they got it wrong last time. The second was that those who have known Tony Abbott for decades were counting on him to blow up - to say something or do something when the cameras were rolling that was going to take him out of contention. The certainty Abbott was going to blow up became an article of faith, the last refuge even into the last week of the campaign itself. Underestimating Abbott began with those who had known him at university: they declared that the student of then was the real, unchanged man of now and was, therefore, of no account. It was a fatal miscalculation.

You do not have to be a good government to gain re-election. You need only be better than the other side. Any prospect of a good government emerging under Kevin Rudd was sunk by the intellectual tenets of the 2007 election campaign. Rudd succeeded in convincing those who wanted a policy continuum minus Howard that they would score such a continuum while, simultaneously, he convinced those who wanted a change of direction with Howard blessedly gone they would get that change. The achievement was nought less than genius and warrants acknowledging. The problem is that there comes a time in the life of a government when consequence rules.

\section{A Government of Limited Possibility}

The ALP campaign of 2007 guaranteed a government of limited possibility was going to emerge. The Rudd Government was cruelled from the outset when it promised to match irresponsible tax cuts in the sum of $\$ 31$ billion and, having been elected, failed to renege on the promise as new circumstance and knowledge surely dictated. In his memoirs, Peter Costello has acknowledged that the succession of tax cuts not once delivered the electoral rewards the Howard Government hoped for. Joe Hockey, on becoming Treasury spokesman, spoke aloud about abandoning the 2007 tax cuts as unnecessary and unhelpful. Wayne 
Swan made his own editorial contribution on the absence of value (economic or political) in the 2007 cuts by omitting all reference to the final tranche in his 2009 budget speech.

What could have been an age of wonders after 2007 became another round of the customary pieties about fiscal rectitude. Notwithstanding that rhetoric, the government unhesitatingly tolerated record levels of public debt in order to combat the global financial crisis. While spending big on infrastructure, it was demanding of the Public Service and the military that they effect economies and cutbacks. Only insolence and sleight of hand made the delivery of public services possible. The failure of the roof-insulation scheme was a failure in public service practice. Good government depends on time and careful thinking, minuted decisions with a course for action. Good government requires the involvement of a competent public service, properly encouraged, working reasonable hours. A viable program for roof insulation required the involvement of public servants, working to a reasonable timetable, who would be expected to draft regulations that set out standards that were enforceable at law. Behind the regulations there needed to be a supervisory force which ensured the standards were metbasic nineteenth-century tenets of government. Good government is secondary when the big effort - the principal ministerial involvement - is devoted to the announcement of the scheme, the when and the where and the visuals. Roof insulation was a scandal. Inadequate resources have a consequence.

The great injection into universities and training did not come to pass. The arts - the whole notion of creative expression - was simply not a part of the government's thinking, not even when thousands of millions of dollars were being splurged on make-work schemes. A consultant's report into the AttorneyGeneral's Department revealed that the principal source of legal advice to the Executive Government on the lawfulness of its proposed actions was not providing that advice. The overworked staff was not providing that advice because funding pressures caused them to concentrate on serving the needs of paying customers.

Their decision was rational in the exact fashion intended by the economic rationalists.

Successive governments have failed to harness the benefits of past productivity improvements. The colossal revenue potential of our present prosperityuntouched by the zephyr that reached Australia from the North Atlantic crisis - continues to be squandered. Governments have handed back the bounty by way of constant revisions downwards of the marginal rates of tax and the proportion to be extracted as taxation. Governments have squandered Australia's prosperity. The competence and capacity of the public sector suffer from the craven failure of successive governments to build a tax system that 
sustains the revenue requirements of Australia's social needs. The challenges will only get harder as the population ages. You cannot have good government unless the government has an adequate and reliable revenue base. The absence of revenue that is adequate and reliable is why each State government is in difficulty. The Commonwealth has a tax base from multiple sources that is adequate and reliable but prefers to squander it in tax cuts and splashy shortterm programs while taking the shortfall out of the hide of public servants. The easy solutions of assets sales are gone now the great public enterprises went for a song.

Winning power by blue smoke and mirrors (against a master of that same game) brings an obvious consequence once you take power. Appearance might be contrived for a good while, task forces and inquiries can stall hard decisions. The day, however, cometh when a government must take decisions or, in not taking them, reveals itself. The punters became aware during 2009 of what was happening before the commentators dared to articulate a gathering impression of the man who then led the government. He says a lot but I am not sure that he means it. Can you work out what this bloke believes in? He says what his audience wants to hear. Does he believe in anything? He talks a lot but nothing happens.

The punters' awakening to disturbing truths came at different moments. The phrase about 'a fair shake of the sauce bottle' came from one who is unconnected with the way Australians speak. No Australian has ever used that phrase in ordinary discourse and no-one ever will. It was very interesting to hear the reactions to the phrase. It proved to be the moment when the penny dropped.

\section{The North Atlantic Crisis}

After the votes were cast, there were those who lamented that the former government failed to claim credit for avoiding what became known as the global financial crisis. We suffered least of all developed countries because Australia alone of the countries in the G20 has a debt ratio as a proportion of gross domestic product (GDP) below 10 per cent. We are also alone below 20 per cent. If you were not exposed to shares and financial services, you likely remained employed, and it was a crisis you did not notice. The Australian Government did not have to nationalise banks and insurance companies, it did not have to prop up motor vehicle manufacturing (any more than it already was, that is), it did not become the owner of much of the nation's housing stock.

That is why its borrowings could go directly into stimulus spending. Ours was a light affair, a setback for Australia not to be compared with 1982-83 or 1990-91, or even the collapse of developers and financiers during 1974-75. 
Being in power and coming through the other side, the government is entitled to take the credit for avoiding recession. Credit for this escape should be shared more generously and belongs to: 1) Chifley's banking reforms in the 1940s; 2) prudential safeguards implemented in the Menzies era; 3) the near-death experience of Westpac in North America in the 1990s, which gave all our banks an aversion to that continent; 4) the mining boom; 5) the decisions of Hawke and Keating to expose the Australian economy to world market forces; and 6) the decision of Howard and Costello to repay all sovereign debt.

The economy did not play big in the campaign. Sound economic management was a given. The assertions of the government, though valid, were met with a ho-hum. The government ruined the chequerboard all by itself because of its decision on an ETS. With remarkable prescience, Paul Kelly (2010) nailed the government's desperation as follows after the debacle at Copenhagen:

The Rudd government is stranded without any apparent game plan on its most important first-term policy (outside its response to the global financial crisis). It is rare for a national government to face this predicament in its first term. Labor seems unable to abandon its ETS yet unable to champion its ETS; it cannot tolerate the ignominy of policy retreat yet cannot declare it will take its beliefs to a double-dissolution election; it remains pledged to its ETS yet cannot fathom how to make its ETS the law of the land. Such uncertainties are understandable, yet they are dangerously debilitating for any government. In such a rapidly shifting policy and political climate, even fallback positions risk being rendered obsolete.

What Kelly was discovering was that the political class in absolute control of Australian Labor is without values. Focus groups will not point a finger in the way of the Promised Land. Only the values of the people making up a government and the party behind those people can provide those values. After the Copenhagen fiasco, the politics of climate change turned on its head. The politics moved from election winner to a matter of no positive electoral consequence unto the single most powerful reason for customary Labor voters to withdraw their first preference from Labor.

\section{A Government of and for Insiders}

A government of the political class is a government of and for insiders. The decision to grant rebates on licensing fees to free-to-air television was symptomatic of a government in its degenerative phase except this was a government not 30 months old. The $\$ 250$ million as a rebate on licences for freeto-air television revealed a government that believed public life and statecraft 
were the preserve of insiders. The Rudd Government was the first to be built on and out of the political class. The political class - being men and women of process - find their way forward by way of focus groups, qualitative polling and talking to each other.

Once upon a time, the intellectual depths of the parliamentary party provided policy sustenance. Not now. Once the decisions of the ALP National Conference provided a program for action. The National Conference is now of no policy consequence. It said much that the 2020 summit took priority as an ideas forum over and above the party notionally in government. It says even more that the outcomes of the summit have disappeared without trace.

\section{Polling Turns South}

Throughout the heady days of 2008 and 2009, becoming nauseated at the flakery that was going down a treat, this writer predicted and wrote that, when the Rudd bubble burst, his descent in the polls would be the most rapid in the history of polling. Newspoll captured what was an ebbing of support for Rudd poll upon poll, gradual to begin, so that in February 2010-many fortnights after Turnbull had departed-Rudd's approval was down 16 points. I predicted a geometric decline in which the ground opened up. The first February poll placed the Coalition's primary vote ahead of Labor for the first time since Howard was riding well. The Coalition lead of 42-41 meant little given the two-party preferred vote had Labor comfortable on 52-48. Rudd, however, had slipped in approval to fifty. The second Newspoll of February maintained all three trends: Rudd down, Labor down, two-party preferred up to 53-47. The first poll of March found the three indicators were broadly steady. The ALP was moving deep into Beazley territory in which the party is travelling well but the leader is the problem.

Was there any mystery in these poll findings? None at all. The drop in support for the party leader was translating into a drop in the ALP vote. Where the support was going tells you much of the rest of the story. When Labor mismanaged the Oceanic Viking, its primary vote drop went directly to the Liberals. The February 2010 drop sprayed-principal beneficiary, the Greens-before returning through gritted teeth as preferences. Greens and 'Other' were sitting on a massive 21 per cent. If such numbers were concentrated in the inner cities, Labor was in trouble in seats such as Sydney, Grayndler, Melbourne, Batman, Cunningham and Newcastle.

The sense of drift was coming back to the Labor machine in strong terms from the focus groups. The groups were reporting a consistent thread of promises unfulfilled, expectations raised, expectations dashed. Something had to be 
done. Fatefully, the government decided to bring inquiries into hospital 'reform' and tax reform to the front of the agenda. A package on hospitals was all but unavoidable as so many voters were expecting a takeover and/or massive injection of Commonwealth dollars into the hospital systems of several States.

The failure with hospitals necessarily begins at the National Press Club in March at which Rudd - then possessed by unbridled hubris - declared war on the States. Only a palooka would so gratuitously insult the very people he was going to need in order to pull off his reforms. Rudd was counting on the financial shortcomings of the States to be matched by a moral deficit in their political leaderships. Rudd was reacting to and mouthing grabs from focus groups that said the States were on the nose. Advice was: there is no downside to attacking the States. Under serious questioning that day, the spectacle was saddening. Briefed in a hurry after squandering two years, pretending that this announcement had a long provenance, he could only bluster when hit with questions outside his briefing. Rudd blustered when he was ignorant.

Hospitals established the template of a Rudd policy announcement

- 12 hours of pyrotechnics

- 48 hours of bluster

- a slow unravelling as the details become known and the explanations do not stack up.

The corker in the hospitals debate was when Rudd behaved totally in character at a meeting with the Premier of New South Wales, Kristina Keneally. Television footage showed a premier trying so hard to be conciliatory but met by a stonefaced Prime Minister, no eye contact, looking vaguely downwards to the table. When Keneally was done, without a comment on her effort, he asked to get down to business. It was a most revealing rudeness.

The health reforms ended in game, set and match to the States. By not agreeing to the proposals announced at the National Press Club, the premiers of New South Wales and Victoria gave up nothing and gained much. Between the first announcement and the meeting of the Council of Australian Governments (COAG), this ever elastic package added extra funds for aged care, training specialists, money for junior doctors, GP training places, emergency departments and the bottomless hole of elective surgery. Some of these announcements were foreshadowed; all measures would have emerged as worthy initiatives in the course of the near future as part of the unending rounds of CommonwealthState health agreements. In early 2011, Julia Gillard announced the abandoning of much of what was agreed to.

The polls were capturing how deeply unimpressed the voters were by the lack of substance that finally emerged from each big announcement. The Newspoll 
published on 4 May 2010 reported that Rudd's approval rating had collapsed to 39 from 51 - the greatest single fall in the history of polling. Labor's primary vote fell a massive eight points to thirty-five.

\section{ETS Abandoned, Mining Tax Announced}

With just two days of April remaining, the about-face occurred on the ETS. For Rudd, the abandonment was the end game. Against a backdrop of falling personal ratings in the published polls, a slide in Labor's primary vote and the asking aloud of questions about personal judgment, Rudd announced the government's response to the Henry Review of taxation. The response concentrated on a new tax on mining companies - said to raise a bonanza in tax receipts that would enable the whole nation to reap the windfall accruing to the miners because of ever-growing demand from China, India and elsewhere for what is won from the ground in Australia. The revenues so won would not go to a sovereign wealth fund. No, it would be spent as reaped - or squandered - on a reduction in company tax rates, a topping up of superannuation to mums and dads (though no tax dollars would actually find their way to such funds), additional infrastructure spending and a budget back in deficit ahead of forecasts.

The problem began with the pyrotechnics of the announcement. The prospects of carrying public opinion were effectively forfeited within a few days. Everyone inside the industry accepted that miners had to pay more tax. The increase might have come about by any of several possibilities - most obviously, extra royalty payments and/or the application of a resources rent tax. Something like this was not far from what the emissaries of Ken Henry had been canvassing, not at all far from the discussions with Martin Ferguson. None of the miners had cause to suspect hostile intent from Wayne Swan or Treasury. They expected the new arrangements would come to pass after the usual consultations, perhaps harsh words along the way but all inside the bounds of customary political discourse. Australia has been there before with petroleum. The Henry Review had been somewhere inside the government for five months; announcements would surely be based on broad expectations raised after which details would go into the maw of a negotiated settlement. It required a special kind of political genius to unite the mining companies against a tax they were expecting. To lose the ensuing debate - a debate in favour of an unanswerable good-required ineptitude beyond any contemporary precedent. The government lost the debate for one reason: Rudd inserted himself.

The then Prime Minister used a press conference on the Henry Review to provide distractions from another week of horrors that his own behaviour, his absence of a compass, had inflicted on the government he led. Front and 
centre of the policy announcement was daring Abbott to block the tax bills. The gambit was intended to position Abbott as being for the miners, against extra superannuation payments to mums and dads and against a reduction in company tax. Laura Tingle used her column the Friday following to describe the preparations for the media announcement. Briefings to tame reporters favoured by the Rudd court concentrated on the coming pleasure of wedging Abbott. The baiters thought they would position Abbott somewhere uncomfortable. That was all there was.

After several months of Abbott's leadership, Rudd's court still did not understand that Abbott will take any dare. Labor's political class did not grasp Abbott is fearless. His greatest strength is his greatest weakness: he believes so strongly in what he believes in that he will do anything in pursuit of those beliefs.

\section{Breakdown in Cabinet Government}

A situation is not helped when so little that matters goes to Cabinet. When it came to adopting the Henry Review, Cabinet gave a tick to the broad outlines. The ministers were as astonished as the mining companies at how Rudd chose to play it. They started to ask of themselves and confidants whether there was any end to the harm this Prime Minister might do.

Any chance of consensus or general acceptance was dashed by the template of announcement first, scorch the opposition, wallow in hyperbole, maximise opposition; insult then consult. Under pressure, in days following, Rudd assaulted BHP and Rio Tinto for reason that their share registers had large numbers of foreigners. It was a xenophobia not seen since Jack Lang was in full cry.

The media conference had no paper to back it up. Rudd could not explain the detail. His knowledge base had been acquired very recently. Definitions shifted day by day of what was the threshold when the tax cut in. The polls were showing a tidal movement away from the major parties. The Newspoll on the first day of June revealed that Labor was going to lose the election. The approval rating for Rudd was down to 35 per cent. When he touched 33, his caucus colleagues were not going to be able to avoid discussing a leader who enjoyed the active hostility of two out of every three Australian voters. Hardheads had decided Rudd was not going to recover. Voters were not embracing the Liberals or Nationals. They turned to the Greens. The 2010 election was going to turn on what proportion of Labor's disillusioned - a critical mass of perhaps the most intelligent voters in the land-were going to return via preferences. Could enough of them really go all the way and put the Coalition ahead of Labor? 
People who cared about the future of Labor made a calculation as follows: barring an act of suicide by the Opposition - which seemed determined to find a cliff to jump off-and barring a decision by the caucus to act on the leadership, the government would go down at the next election. The lack of quality in the Liberal Party was not going to matter.

In mid-May, the polling companies were beginning to report a separate horror about the trouble for Labor in marginal seats in Western Australia and Queensland. The Morgan poll and private polling confirmed difficulties in Leichhardt, Flynn, Dawson and Herbert in Queensland; and in Swan, Hasluck, Stirling and Cowan in Western Australia.

Civil society took a battering when an objective, discoverable number such as actual taxes paid by the miners was a subject for vicious, partisan contest. Australia's national institutions are part of the thin thread that preserves our civilisation. While ever the basic institutions of Treasury, the Reserve Bank, the Australian Taxation Office, the Bureau of Statistics, the Electoral Commission and the armed forces are in the hands of people of integrity, Australia can survive any government.

\section{A Final, Fatal About-Face}

Beaten hollow in the debate, the government decided to spend tax dollars on government advertising in support of the mining tax. The weakness of Rudd determined this desperation. Unable to afford another about-face when, this time, an about-face was good policy, Rudd authorised an about-face of spectacular proportions to spend tax dollars in defence of his lost cause. Rudd had been crystal clear ahead of the 2007 election that party-political government advertising would come to an end. Government advertising in support of the political programs of a government, any government, was (said Rudd in 2007 over and over) 'a long-term cancer on democracy'. So it was. This about-face proved to be the final straw. Labor operatives not usually concerned with high standards of governance did understand what this betrayal meant. They spoke to each other and select others. One sentence sums up volumes of self-searching: 'If the caucus does not act, the nation will.'

When it came, the end was swift. The end was always going to be swift. Rudd lacked a friend or ally. His only factional base was high ratings in Newspoll. An alliance of convenience had become inconvenient. The fall was always going to be sudden - a surprise when it was finally launched, obvious and inevitable in retrospect. 
For months the caucus had avoided addressing the certainty of defeat. Slowly but surely, all the rationalisations perished-first-term governments do not lose, people will not want to admit they were wrong - until all that remained was the codswallop that the punters will not vote for Abbott. As June was ending, the emptiness of that hope was shot. People were not prepared to vote for Abbott so much as they were determined not to vote for the government. Abbott was in a sweet spot and keeping low. Move then to the Victorian ALP right. One salient move directly to Julia Gillard - a foray sufficient to know her refusal was not a final word; a second foray to the NSW right where they discovered an enthusiasm equal to their own. It was not a lot of effort to establish pretty well all the right across Australia was united and ready to strike.

\section{Perfect Strike}

A story was planted in the Sydney Morning Herald that a staffer for the Prime Minister was canvassing support. In the cause of that canvass, he had reflected on the loyalty of the deputy. The story could not be planted in Melbourne. It did not matter that the story was not true. The substance of the story belies its truth; if it was true that a staffer was canvassing, the canvassing would have revealed itself to Gillard and others even as the canvass was taking place. Activity of that magnitude does not a secret remain.

Truth was not a critical factor; impact was. Gillard was prepared to believe that her leader was capable of such behaviour. Her colleagues and circle were hearing and seeing the shift in the electorate. Loyalty counted for only so much. Her defenders are entitled to observe she had offered more loyalty than was rational. Was the Deputy Prime Minister expected to sit on her hands so as to allow the government to proceed to certain defeat? Anyone who knows how politics works knew that the position for the government was irrecoverable. The leader had lost respect across the spectrum.

On the Tuesday going into Wednesday as June was ending, the arithmetic in caucus worked like this: the national right plus Gillard's support base plus those recognising the need for change equals 100-plus MPs and senators in a caucus of one hundred and twelve. Or you can write the same numbers in a different way: deep personal loathing (an absolute majority in its own right) plus terror of losing plus doing the right thing by the party equals 100-plus. However you counted, a spill was certain. Loyalty was not a card anyone was prepared to play. The caucus felt not a shard of loyalty was owing. A leadership contest would come to pass in which the leader would be struggling to poll two handfuls.

Sentiment, not reality, changed in 2010. The reality was constant; the reality was unpleasant. Sentiment changed when caucus members apprehended the one win 
they thought was in the bag was not going to happen. The certainty of defeat concentrates a mind powerfully. The leadership group in the governmentall those in regular contact with the then leader-knew that the problem was personal. The mining tax had become a killer, an unnecessary war that the government was losing. The inner circle was as heartily sick as the punters at hearing the same words recited in defence of the tax as if repetition replaced the need for argument. The net effect of a government becalmed was an exponential shift in votes away. One-quarter of the Australian electorate had taken refuge with the Greens and 'don't know'.

\section{In An Election in Which Neither Side Deserved to Win, Neither Side Won}

Surely, there was no mystery about what happened on election day. Bad governments are treated harshly by the electorate. The government that fell without a shred of glory on 21 August was a very bad government. Without a record to vaunt and no program for the future, the leadership of the government and the ALP machine offered a campaign that was devoid of sparkle, ideas and conviction. The absence of intellectual depth to Labor's campaign came as a surprise to outsiders. Acres of newspapers and hours of broadcast time were devoted to 'discovering' that belief had departed Australian Labor. Believe in something, you attract and repel support. Believe powerfully, advocate rationally, get out and about driving ideas, you will also win respect. In elected office, beliefs are supposed to be the driving force to implement what you promised. If the electorate is unimpressed, you set about persuading the electorate of the correctness of your course. You do not retreat because of poll numbers. If the numbers are adverse, engage in an art you grew up understanding was intrinsic to Labor: the art of persuasion.

The Greens are backed by idealism and all the energy of youth. Now they are sanctified by a formal alliance with a minority Labor government. The alliance confers legitimacy on a political force whose central strategic purpose is the elimination of Labor as the alternative to mainstream conservatism - a mission made easier by Labor's redefining of itself as a party to the right of centre. It is remarkable that Labor is referred to without challenge by friend and foe alike as a 'brand'. Not a project, not a mission. 'If we are not a crusade we are nothing,' once declared Harold Wilson of UK Labour. Australian Labor is not a crusade; Labor is what it is: the rhetoric of the hour, words for the moment when only words will do.

Labor's model of governance is discredited. Caucus members have become abject servants of the will of the leader. Servitude will last as long as the poll numbers 
remain high. During it, there is no discussion, debate or discourse. The leader enunciates by diktat: his or her authority is accepted without question, usually with toadying. When the numbers fall, the phase ends. The end is swift. Total surrender is followed by assassination without an intervening period of soul searching. The electorate took a harsh view of the swiftness of assassination, as necessary as it was in June 2010. You cannot run a government this way.

For the moment and for maybe three years more, Labor can rely on the army of salaried staffers and taxpayer-funded postage, printing, telephones and electronic mail to offer the impression that the party is something more than a few hundred insiders. Without a party membership out there, the trickery and puffs of Labor's parliamentary leadership will have to be dead right. Labor has proven it can win elections without a party membership. Now it has no choice.

\section{References}

Cavalier, Rodney. 2009. 'Realigning the Planets: When Kevin took a walk down the corridor for a quiet talk with Kim, the next federal election was decided'. Australian Cultural History 27(2): 195-204.

Kelly, Paul. 2010. 'Labor in denial as ETS fairyland fractures'. The Australian, 24 February. 